\title{
Landfills: Problems, Solutions and Decision-making of Waste Disposal in Harare (Zimbabwe)
}

\author{
M.D. Kharlamova, Sheron Yeukai Mada and V.A. Grachev \\ Peoples Friendship University of Russia, Ecological Department 113093, \\ Podolskoe roadway, 8/5, Moscow, Russia. \\ http://dx.doi.org/10.13005/bbra/2034
}

(Received: 29 December 2015; accepted: 28 January 2016)

\begin{abstract}
Selection of a suitable site for constructing a new landfill is one of the most challenging issues for town planners in developing countries. A study was conducted to locate the most suitable site for constructing a sanitary landfill in the city of Harare using Geospatial techniques and Multi-Criteria Evaluation. To identify appropriate landfill sites, nine input map layers including proximity to settlements/built up area, proximity to protected areas, proximity to airports, proximity to road and railway networks, surface water, slope, elevation and soil type were used for mapping, analysis and evaluation. Each criterion was identified and weighted using Analytic Hierarchy Process. A final map was generated which identified potential areas for the location of a landfill site. Results revealed that $1.31 \%$ of the total area of Harare was identified as mostly suitable, $\mathbf{2 4 . 7 3 \%}$ as moderately suitable to suitable and $\mathbf{7 6 . 9 6} \%$ as unsuitable to construct a sanitary landfill. Six sites were identified as most suitable sites for a landfill. These selected sites require further geotechnical and hydrogeological analyses to identify the final site in the city to construct a sanitary landfill.
\end{abstract}

Key words: Sanitary landfills, types of solid waste, waste disposal practices, Integrated solid waste management, Multi Criteria Decision Analysis, Landfill selection, Harare, Zimbabwe, Pomona

Dump, Slope map criterion, GIS, overlay operations, analytical hierarchy process (AHP)

One of the many challenges facing town planners today in developing countries is selecting the most suitable area for disposing municipal solid waste. Solid wastes that are generated from industrial organizations and residential areas create serious environmental problems. There are various techniques used for solid waste management such as landfilling, thermal treatment, biological treatment, and recycling. Landfill is the most costeffective system of solid waste disposal for most urban areas in developing countries. A sanitary landfill is a site for the disposal of waste materials by burial and is the oldest form of waste treatment throughout the world. Landfill selection in an urban area is a critical issue in the urban planning process because of the impacts on the environment and health of the area. Numerous factors have to be evaluated to minimize the environmental impacts.

\footnotetext{
* To whom all correspondence should be addressed.
}

The construction of a landfill and its location should also be in accordance with the respective regulations within a country.

Landfill site selection today is a major challenge because the disposal site must not cause damage to the biophysical environment and the ecosystems of the surrounding. Also, economic factors and geomorphologic features must be considered during site selection for the solid wastes. Most local governments in developing countries are unable to deliver services effectively and dumping of municipal solid waste (MSW) on undesignated areas such as open dumps is a common practice, resulting in a strain on the environment (Practical Action, 2006).

Inefficient solid waste management leads to substantial negative environmental impacts, for example, pollution and health and safety problems. Uncontrolled disposal of waste is detrimental to human health because it creates unsanitary 
environments that have adverse impacts on urban residents. Where sanitary facilities are scarce, household solid wastes also tend to be mixed with fecal matter, further compounding the health hazards (Kjellen, 2001). Solid waste disposal is one of the problems faced by city planners throughout the world.

\section{Problem Statement, Location and Particularities of Study Object}

Zimbabwe is a landlocked country located in Southern Africa. It has a population of 13.72 million with a projected annual urbanization rate of 2.2\% (ZIMSTAT, 2013). Harare is the capital city of Zimbabwe, which is located in the north-east part of the country, covering an area of $960.6 \mathrm{~km}^{2}$ at an elevation of $1483 \mathrm{~m}$. The residential areas of Harare are managed through 24 district offices, 15 of which are in the high density suburbs and 9 in the medium and low density suburbs. It is estimated that there are 121,724 residential properties in the high density and 59,475 in medium and low density areas to give a total residential housing stock of 181,199 (Housing and Community Services, City of Harare, personal communication, 2011). A demographic and health survey carried out in 2010 indicated that $60 \%$ of the population are poor and cannot meet their basic needs (ZIMSTAT, 2013).

The city of Harare is located on a watershed plateau between two major rivers, the Limpopo River and the Zambezi River, yielding some of Zimbabwe's best agricultural soil (Kisner 2008). Harare has several rivers and streams; the Manyame River is the main river, which flows in the southwestern part of the city into Lake Chivero. This lake is the main source of water for Harare and surrounding areas. The annual average temperature is $17.95^{\circ} \mathrm{C}$ and annual average rainfall is $840 \mathrm{~mm}$. The climate supports natural vegetation of open woodland.

Harare is relatively better developed than all other provinces of the country, housing a heavy industrial area; it has the highest number of people and relatively good road network and other facilities such as schools, hospitals, tourism and agriculture (GoZ, 2011). It is Zimbabwe's leading financial, commercial, and communications center, and a trade center for tobacco, maize, cotton and citrus fruits. Manufactured goods include textiles, steel and chemicals, and gold is also mined in the area. Railways connect Harare with Zimbabwe's neighboring countries.
Reduction of goods production in Zimbabwe gave way to informal importation of different types of goods, which also raised new challenges in waste management especially packaging waste. According to Practical Action (2006), the high unemployment rate also gave rise to a vibrant informal sector both in the urban areas and in rural growth points, which also resulted in high generation of unmanaged waste. Waste that is not properly managed, especially excreta and other liquid and solid waste from households and the community, are a serious health hazard and lead to the spread of infectious diseases. Unattended waste lying around attracts flies, rats, and other creatures that in turn spread disease. Normally it is the wet waste that decomposes and releases a bad odor. This leads to unhygienic conditions and thereby to a rise in the health problems. This is also contributing to soil and water pollution in the city and contributed to the outbreak of diseases, which are associated with unsanitary environments such as diarrhea, cholera, typhoid and dysentery (M.S.Eukay, Kharlamova M., 2014).

The rapid growth of Harare (Zimbabwe) has resulted in increased consumption of resources to meet the growing demands of the urban population and this has led to the generation of large amounts of wastes, (Practical Action, 2006). The rate of urbanisation has not matched the rate of infrastructure development in the city of Harare which has increased the challenges in waste management. Since 2000, waste collection and management systems have been collapsing due to the economic crisis and shortage of foreign currency and the hyperinflation environment (Masocha, 2003). This has pushed the cost of services beyond the means of the Harare City Council and it has not managed to construct a properly engineered solid waste disposal site. As a result, solid waste has not been collected efficiently.

The mean per capita generation rate and household generation mean in Zimbabwe are 0.327 $\mathrm{kg}$ and $2.079 \mathrm{~kg}$ per day, respectively. The mean residential per capita generation rate for Harare is $0.361 \mathrm{~kg}$ a day while the household mean generation per day is $2.108 \mathrm{~kg}$ (Tirivanhu and Feresa, 2013). Figure 1 shows that the mean household generation rate is highest in high density suburbs followed by medium density suburbs with the lowest generation rate in low density suburbs. 
The waste generated in Harare consists of biodegradable (62\%), plastic (11\%) and paper (10\%), with metal at $5 \%$, glass, textile, and sanitary waste all at $4 \%$, with electronic waste making the remaining 2\% (UNEP, 2011). Table 1 shows the type of solid waste generated in Harare.

\section{Waste Disposal Practices in Harare}

The final disposal of waste is another major challenge in waste management in Harare.
Currently the city of Harare does not have an engineered sanitary landfill; the waste generated in the city is dumped at Pomona and Golden Quarry dump sites. The Golden Quarry landfill site is an abandoned gold mine, which started operating as a landfill in 1985 to reclaim the land by filling the shafts and pits. It is located about $7 \mathrm{~km}$ to the west of the Central Business District (CBD). Golden Quarry site is mainly industrial and hazardous

Table 1. Type of solid waste generated in Harare (Source: Tsiko and Togarepi, 2012)

\begin{tabular}{|c|c|c|}
\hline Source & Waste Generators & Type of solid wastes \\
\hline Household/Domestic & $\begin{array}{l}\text { Single and multi-family } \\
\text { dwellings }\end{array}$ & $\begin{array}{l}\text { Food wastes, paper, cardboard, cans, } \\
\text { leather, wood, glass, batteries and } \\
\text { hazardous household wastes, fertilizers, } \\
\text { rat poison }\end{array}$ \\
\hline Commercial & $\begin{array}{l}\text { Shops, markets, office } \\
\text { buildings, restaurants, bars }\end{array}$ & $\begin{array}{l}\text { Packaging material (cardboard/plastic), } \\
\text { paper, wood shavings, food waste, } \\
\text { electronic waste, wood preservatives }\end{array}$ \\
\hline Industrial & $\begin{array}{l}\text { Light and heavy manufacturing } \\
\text { and packaging industries }\end{array}$ & $\begin{array}{l}\text { Plastic, paper, electronic waste, food } \\
\text { wastes, cans, steel/ metal, fabrics, } \\
\text { fertilizers, leather, rubber, pesticides }\end{array}$ \\
\hline Institutional & $\begin{array}{l}\text { Police camps, schools, } \\
\text { hospitals, prisons }\end{array}$ & $\begin{array}{l}\text { Food waste, paper, plastics, needles, } \\
\text { syringes, expired drugs, other medical } \\
\text { waste }\end{array}$ \\
\hline $\begin{array}{l}\text { Municipal Services/ } \\
\text { Street Sweepings }\end{array}$ & Streets & $\begin{array}{l}\text { Leaves, paper, human and animal } \\
\text { excreta, glass, cans, paper }\end{array}$ \\
\hline Construction debris & Construction sites & $\begin{array}{l}\text { Wood, concrete, steel and metals, glass, } \\
\text { cardboard, paper, bricks, }\end{array}$ \\
\hline
\end{tabular}

Table 2. Digital Elevation Model (DEM) of Harare

\begin{tabular}{lcccc}
\hline Data & Format & Resolution & Scale & Coordinate System \\
\hline Landsat 4-5 TM & tif & $1000 \mathrm{~m}$ & $1: 10000$ & WGS84 \\
\hline
\end{tabular}

Table 3. Land cover classification scheme

\begin{tabular}{ll}
\hline Land Cover Type & Description \\
\hline Water & Streams, rivers, dams \\
Built up/Settlement & Structures, network of streets, tarmac surfaces \\
Woodland & Dense trees with well-developed grass cover \\
Crop fields & Cultivated areas \\
Bare areas & Exposed rock, undeveloped area, gravel, no form of vegetation \\
\hline
\end{tabular}

Table 4. Landsat Image

Tile Size

Pixel Size

Geographic Coordinate System

DEM Output Format
3601 x 3601 (1 x 1)

1 arc-second

Geographic latitude and longitude

GeoTIFF, signed 16-bit, in units of vertical meters Referenced to the WGS84/ EGM96 geoid 
materials about $90 \%$ with $10 \%$ being household waste from nearby high density suburbs.

The Pomona Dump was created in 1984. It is located $12 \mathrm{~km}$ to the north of the CBD. This disposal site is an open dump which is not lined. According to the Statutory Instrument 6 of 2007 Environmental Management (Effluent and Solid Waste Disposal) Regulations 2007 of the Environmental Management Act [Chapter 20:27] requires urban areas to have engineered sanitary landfills. Open dumping of waste does not have monitoring measures to control operations, as compared to sanitary landfills. Uncontrolled open dumps have no strict environmental regulations; they pose major public health threats, and also affect the natural environment.

Table 5. Buffer Zones

\begin{tabular}{ll}
\hline Criteria & Buffer zone \\
\hline Surface water & $1,000 \mathrm{~m}$ \\
Protected areas & $500 \mathrm{~m}$ \\
Settlements/built up areas & $1,000 \mathrm{~m}$ \\
Railway & $1,500 \mathrm{~m}$ \\
Road Network & $1,000 \mathrm{~m}$ \\
Airport & $2,000 \mathrm{~m}$ \\
\hline
\end{tabular}

When the Pomona dumpsite was constructed, the solid waste was first spread into thin layers, then compacted and finally covered with at least $0.20 \mathrm{~m}$ of soil. However, due to the collapse in waste management and maintenance systems, at the present moment the waste is left uncovered. As a result, plastic and paper waste is blown away by the wind, littering the area around the dumpsite. There are also perennial fire outbreaks at the dumpsite. These fires spew out dark toxic smoke into the atmosphere, which is both a health and environmental hazard. The largest fire broke out in October 2013; it burnt for two weeks killing one person, (Mupedziswa, 2009).

Pomona dumpsite was not engineered, designed, or lined with clay. Unlined dumps

Table 6. Scale of pairwise comparison scale for AHP preferences

\begin{tabular}{ll} 
Number (Value) & Priority \\
\hline 1 & Equally preferred \\
3 & Moderately preferred \\
5 & Strongly preferred \\
7 & Very strongly preferred \\
9 & Extremely preferred \\
\hline
\end{tabular}

Table 7. Pairwise comparison Matrix

\begin{tabular}{|c|c|c|c|c|c|c|c|c|c|c|}
\hline Criteria & $i$ & ii & iii & iv & $v$ & $v i$ & vii & viii & $i x$ & Weights \\
\hline$i$ & 1 & 1 & 2 & 3 & 4 & 5 & 6 & 7 & 9 & 0.259267 \\
\hline$\ddot{i i}$ & 1 & 1 & 2 & 3 & 4 & 5 & 6 & 7 & 9 & 0.259267 \\
\hline iii & 0.5 & 0.5 & 1 & 3 & 3 & 3 & 3 & 4 & 5 & 0.147988 \\
\hline iv & 0.33 & 0.33 & 0.5 & 1 & 2 & 2 & 3 & 4 & 5 & 0.106635 \\
\hline$v$ & 0.25 & 0.25 & 0.33 & 0.5 & 1 & 2 & 2 & 2 & 4 & 0.071947 \\
\hline$v i$ & 0.2 & 0.2 & 0.33 & 0.5 & 0.5 & 1 & 2 & 2 & 3 & 0.056883 \\
\hline vii & 0.16 & 0.16 & 0.33 & 0.33 & 0.5 & 0.5 & 1 & 2 & 2 & 0.04244 \\
\hline viii & 0.14 & 0.14 & 0.25 & 0.25 & 0.5 & 0.5 & 0.5 & 1 & 2 & 0.033049 \\
\hline$i x$ & 0.11 & 0.11 & 0.2 & 0.2 & 0.25 & 0.33 & 0.5 & 0.5 & 1 & 0.022524 \\
\hline
\end{tabular}

$\lambda_{\text {max }}=9.21, \mathrm{CI}=0.0271, \mathrm{RI} 9=1.45$ and $\mathrm{CR}=0.0187 \leq 0.1$

increase the rate of soil and groundwater contamination from leachates. The solid wastes at the dumpsite also consist of hazardous materials and at times human fecal matter and when it rains that waste goes into ground water contaminating water sources of which residents now rely on water from wells and boreholes due to water shortages in the city. Since 2008 there cholera and typhoid outbreaks in the city mainly due to the unsanitary conditions in the residential area and consumption of water from contaminated sources. For example, in 2009, a total of 19,517 cases of cholera were recorded in Harare (WHO, 2013).

According to The Environmental Management Authority (EMA), the Pomona dumpsite is posing a serious hazard to the environment and people who live close to the dumpsite. EMA (2009) stated that the Harare City Council has also failed to register the Pomona dumpsite under the EMA regulations. EMA 
regulations demand that all dumpsites be registered to enable the authorities to carry out regular inspections and curb cases of pollution and other related health and environmental hazards. Due to the various negative impacts associated with dumping of waste at the Pomona Dump, there is need to locate a most suitable place to construct a properly engineered sanitary landfill according to the regulations of the Environmental Management Act (Chapter 20:27). The Statutory Instrument (SI) 6 states that "no person shall dispose general waste or hazardous waste at any other place except in a licensed general landfill or a hazardous waste landfill”. With regards to local authorities who did not have landfills when SI 6 of 2007 was gazetted, these "shall not continue to use an old unlined solid waste site for more than five years from the date of publication of the SI". Thus all the local authorities were required to have moved from dumpsites to landfills by the end of 2012. In Harare, a sanitary landfill site has not been constructed yet. Therefore, the purpose of the study is to locate the most suitable landfill site in Harare.

Integrated solid waste management

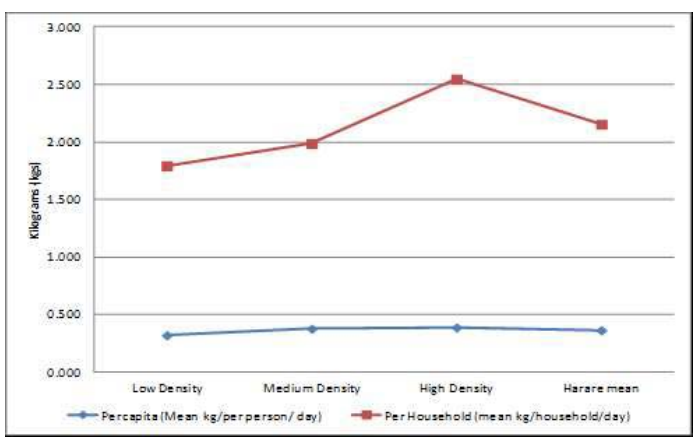

Fig. 1. Waste generation rates (Source; Tirivanhu and Feresu, 2013)

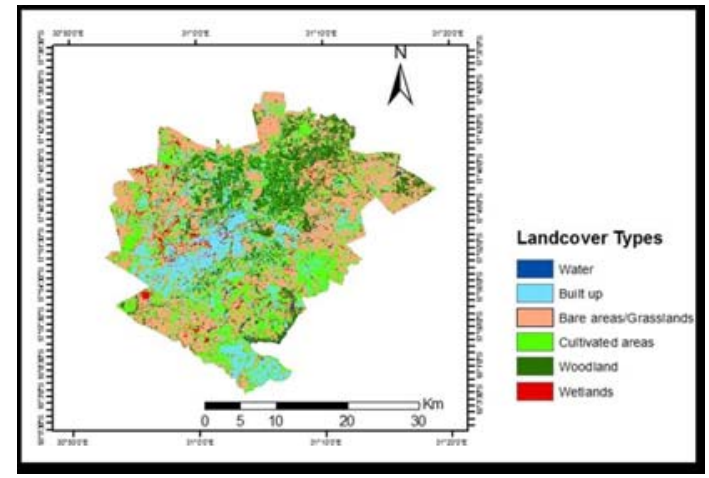

Fig. 3. Land cover types of Harare includes the selection and application of suitable techniques, and management programs to achieve specific waste management objectives and goals. The components of an Integrated Waste Management System, depicting how waste ends up at a landfill are shown in Figure 2.

Therefore Solid waste management procedures include:

$\begin{array}{ll}\text { 1. } & \text { Source reduction } \\ 2 . & \text { Recycling } \\ 3 . & \text { Waste transformation } \\ 4 . & \text { Landfilling } \\ & \text { Warith (2008) stated that source reduction }\end{array}$ and waste minimization, resource recovery and recycling, waste processing and treatment, combustion and landfilling have all significantly affected the sufficiency of waste management systems. Of all available management options for solid waste management, landfill disposal is the most commonly used worldwide. The major goal of the landfill site selection process is to ensure that the disposal facility is located at the best location possible with little negative impact to the environment or to the population. For a sanitary

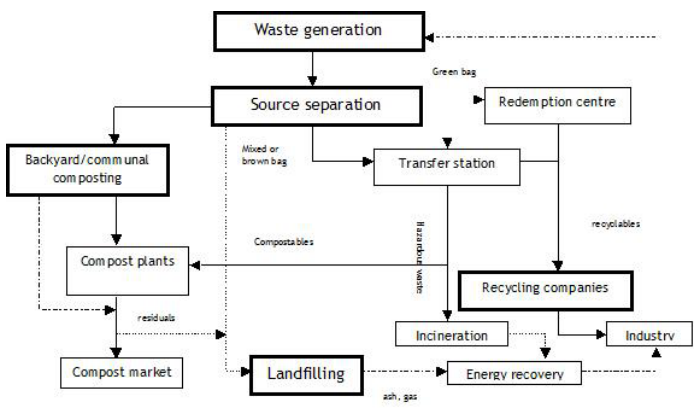

Fig. 2. Integrated Solid Waste Management System

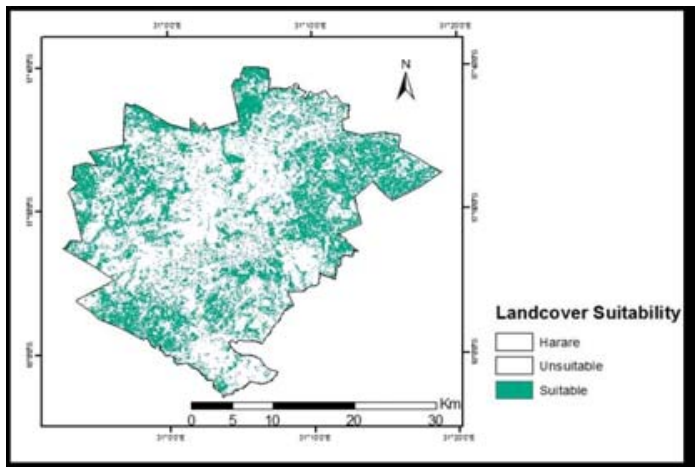

Fig. 4. Land cover suitability map 
landfill siting, a substantial evaluation process is needed to identify the best available disposal location which meets the requirements of government regulations and best minimizes economic, environmental, health, and social costs.

The Harare City Council is responsible for the management of waste in the city. The main management strategy has been collection, transportation and disposal of municipal solid waste on dumpsites. The Zimbabwean laws (the Urban Councils Act [Chapter 29:15] and the Rural District Councils Act [Chapter 29:13] and the Local Authorities by-laws) require the local authorities to carry out door-to-door collection of domestic solid waste in urban centers including growth points. According to Tirivanhu and Feresu (2013), the national mean collection of residential solid waste in 2011 was $52 \%$, while $28 \%$ of the solid waste was buried, $11 \%$ burnt, $6 \%$ dumped on undesignated dumpsites and 3\% recycled.

The other mode of collection has been central communal container collection in highly populated low-income areas where skip trucks go in to hoist skip containers that have been placed at sanitary sites within the communities. Such containers are filled with waste by householders who cannot afford the house-to-house services. The frequency of collection here depends on the rate at which the containers become full.

\section{Methods and Instruments}

Several countries like Australia, Malaysia, Niger and United States among others have put in place guidelines for selecting suitable sites for sanitary landfills for waste management. These guidelines and policies act as the primary mechanism used to protect the environment and avoid nuisance to the host community.

Multi criteria Decision Analysis (MCDA) approach is commonly used to solve the landfill site selection problem and provide decision makers the most satisfactory and preferable alternative. The principle of the method is to divide the decision problems into smaller more understandable parts, analyze each part separately and then integrate the parts in a logical manner. Normally there are 15 environmental, social and other factors which are used to determine the appropriateness of a site to be used as a sanitary landfill. Financial and economic criteria for landfill site selection (such as Cost of Land, Material \&Transport, Costs for the after-care) are also taken into account.

In Harare case the site selection model involved three steps: multi-criteria evaluation, preliminary analysis and identification of the most suitable site. The Analytic Hierarchy Process (AHP) was selected for the decision rules to analyze the data for landfill site selection using GIS. The 9point scale used in typical analytic hierarchy studies ranges from 1 (indifference or equally preferred) to 9 (extreme preference or absolute importance).
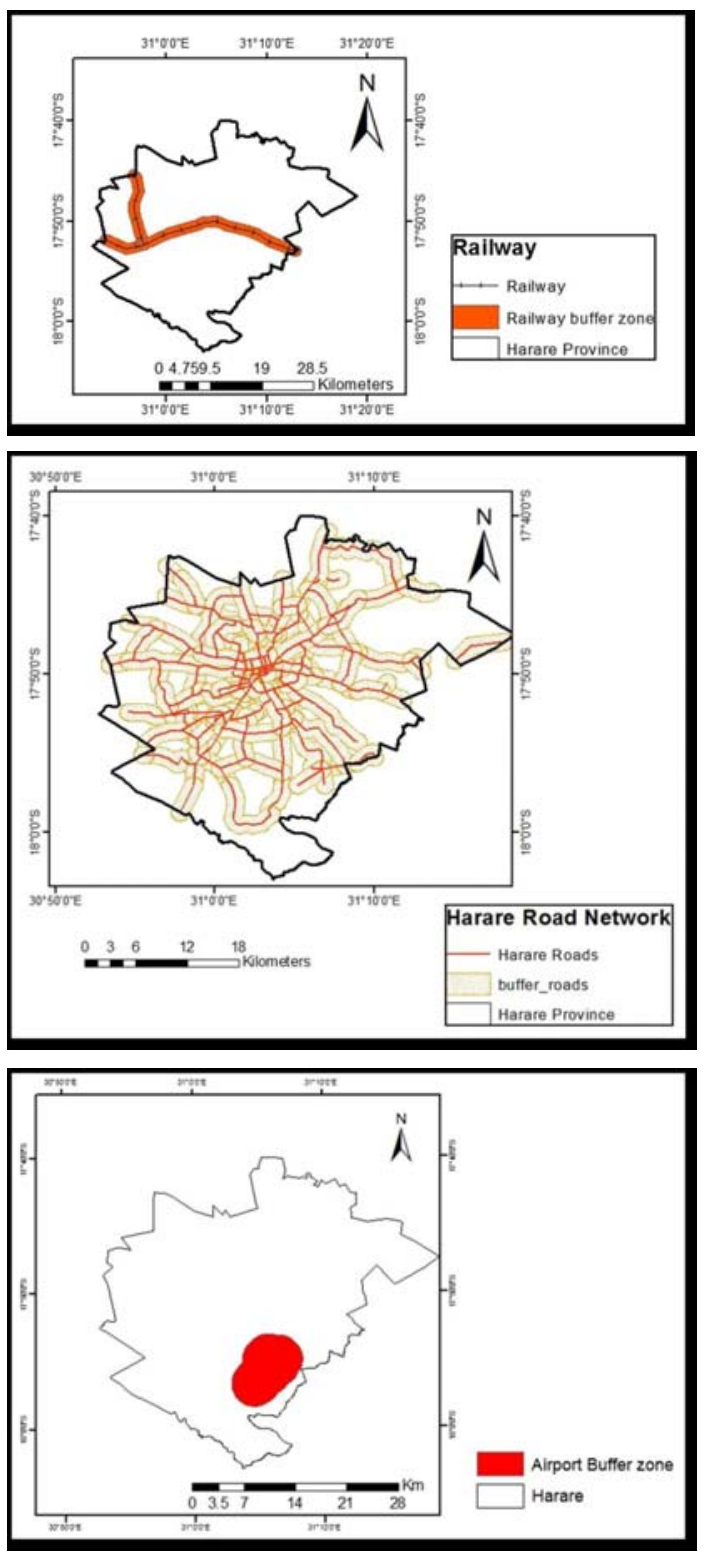

Fig. 5. Buffer zones of roads network, railways and airport 
The parameters analyzed were: elevation, slope, soil type (clay content \%), land-cover type, proximity to built-up areas/settlements; roads and railway lines; rivers; proximity to environmentally sensitive areas, proximity to airports.

\section{Data Sources}

Landsat 4-5 TM (14/05/2009) was used to map the current land use/land cover of the study area. The DEM (Table 2) was used to derive slope, aspect and elevation of the study area.

\section{Land Cover and Land Use Mapping}

Landsat satellite imagery was used to classify land cover into different classes. A supervised classification algorithm (maximum likelihood) was used to classify the satellite image in ArcGIS 10.2. A minimum of 40 remotely sensed ground reference points per class was used to check the accuracy of the classification process. Prior to classification, the satellite imagery was converted from digital numbers to reflectance. Atmospheric correction was done on the image in order to remove the effects of the atmospheric conditions, particularly haze. The geometric accuracy of the satellite was also assessed using

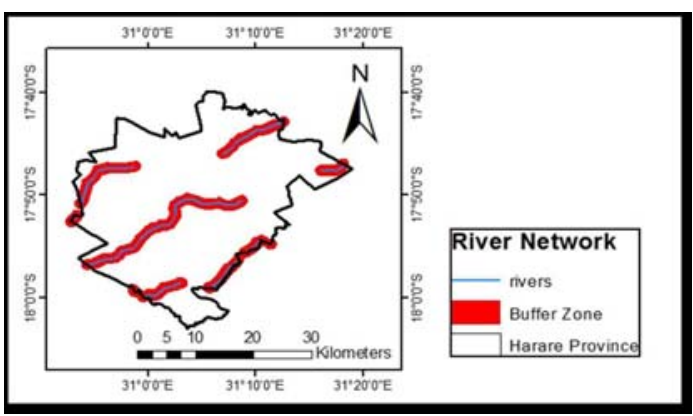

Fig. 6. Buffer zones of rivers

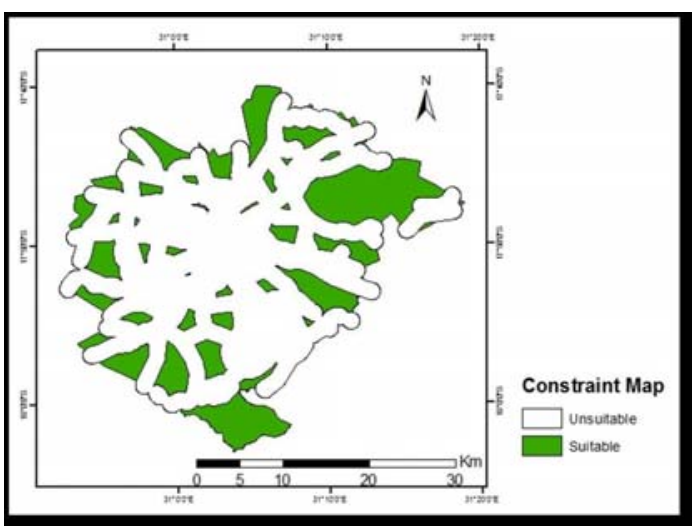

Fig. 8. Final constraint map remotely sensed ground control points. Various data sources were used to delineate the land use in the area. Existing land use maps, topographic maps, Google Earth, were used to produce a current land use map. Five land cover types were identified in the study area as shown in Table 3.

\section{Slope, Aspect and Elevation}

In order to calculate slope, elevation and aspect values, Digital Elevation Model (DEM) of Zimbabwe was used and values were classified by using the 3D Analyst extension in ArcMap Software. The Landsat Image obtained from the USGS database (Table 4) was used to analyze the land cover and land use patterns of Harare.

Slope map criterion was calculated using DEM with 30x30m resolution. Areas above than 20 percent were selected as unsuitable areas for landfill siting. Data on groundwater depth, lithology, and soil type were obtained from the USGS database. Data on waste generation and composition were obtained from the Environmental Management Agency of Zimbabwe.

\section{Data Analysis}

In this study, the first step was to identify

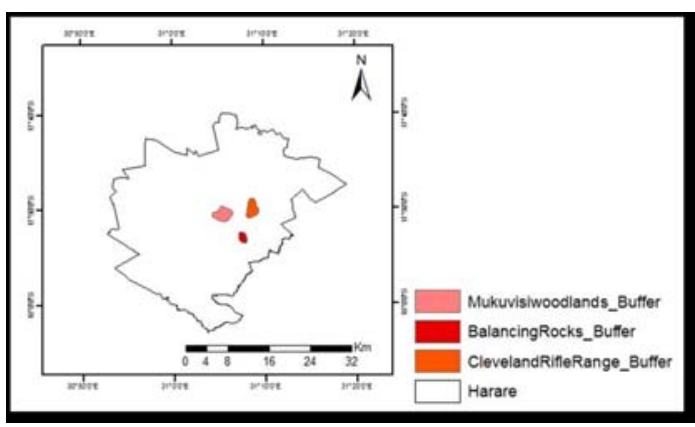

Fig. 7. Protected area buffer zone

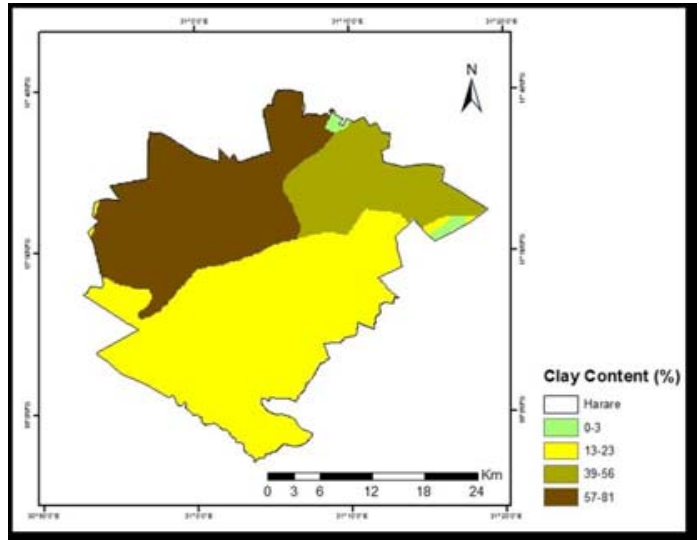

Fig. 9. Clay content percentage of Harare soils 
the environmental, social and economic factors to be considered for siting landfills and defining criterion based on international and local regulations. For preparing a comprehensive database, 12 input map layers, including settlements/built up area, roads, railways, airport, protected areas, slope, lithology and groundwater depth, surface water, slope, elevation and aspect were obtained and prepared in a GIS environment. All layers were converted to the individual raster maps.

Landfill site selection was performed using ArcGIS 10.2 with an Analytic Hierarchy Process (AHP) extension. The AHP divides the decision problems into understandable parts; each of these parts is analyzed separately and integrated in a logical manner (Saaty, 1993). ArcMap in ArcGIS 10.2 was used to digitize maps into different classes based on the satellite image which is the basis of this study. ArcMap was also used to construct the constraint and factor maps. The AHP extension was used to calculate weights for each option and

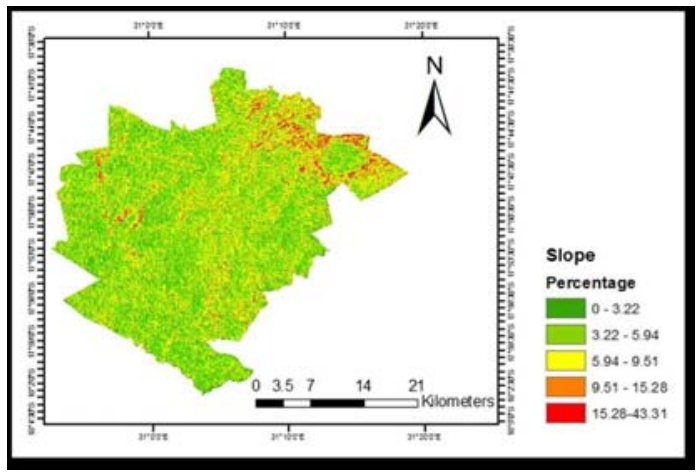

Fig. 10. Slope map of Harare

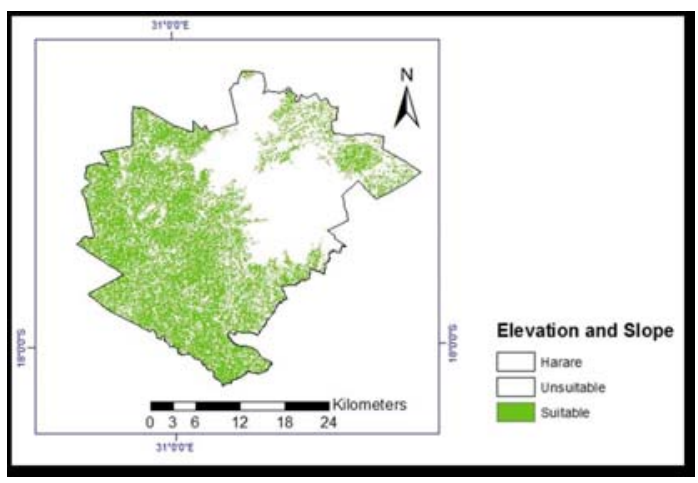

Fig. 12. Slope and Elevation Suitability Map criterion in MCA. AHP is a linear additive model which is widely used in Multi Criteria Analysis, the input for AHP is the answer to "How important is $\mathrm{X}$ relative to $\mathrm{Y}$ ?” for every criteria and option.

Factor and constraint map layers were created using ArcMap spatial analysis operations. This included buffer zoning, neighboring computation, and geo-processing tools (buffering, overlaying dissolving, classification, clipping, and querying). The parameters were identified in accordance with the Ministry of Environment and the Environmental Management Agency of Zimbabwe regulations for waste disposal site selection. The evaluation criteria were classified into two main categories according to how they are considered to affect the landfill site suitability. These are environmental and social, technical and economic factors. In the study area, nine parameters were considered in the site selection process surface water, elevation, slope, soil type, airport, distance to railways, protected areas, distance to roads, and settlement were selected for the

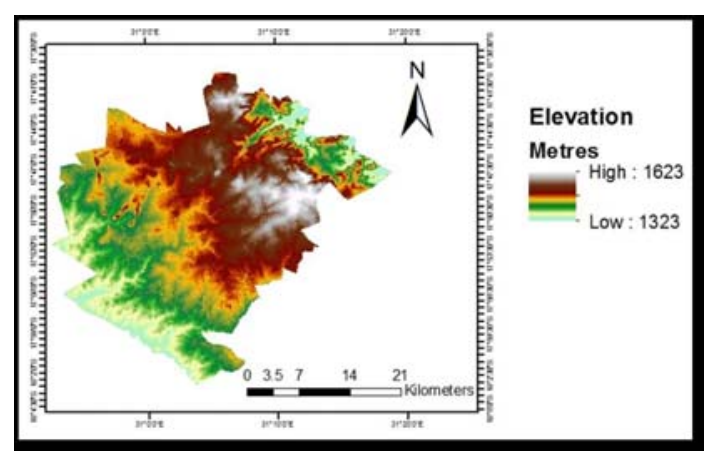

Fig. 11. Elevation of Harare

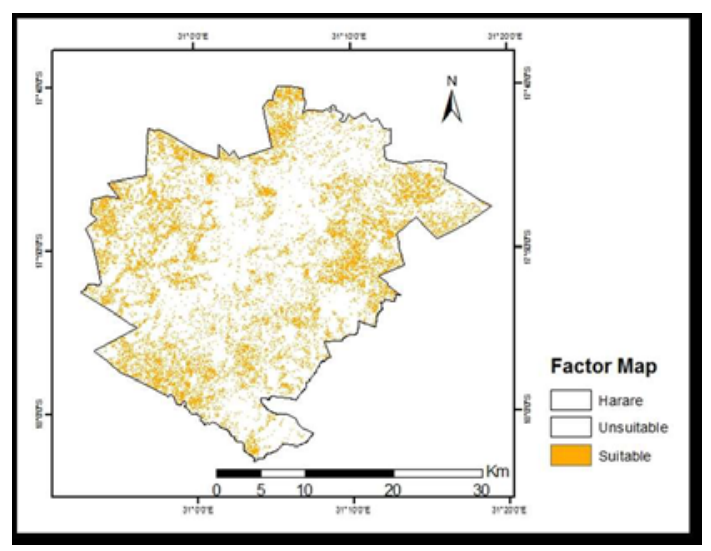

Fig. 13. Final Factor Map 
computation process. The constraint maps are road network, railway network, surface water settlements/built up areas, airport and protected areas. The buffer zone constructed for each parameter is shown in Table 5. The factor maps included soil type, slope, and elevation

The analysis was in two stages where unsuitable parcels of land for siting a landfill were eliminated. The identified suitable parcels of land after the elimination process were evaluated using the analytical hierarchy process (AHP) Multi Criteria Decision Making (MCDM).

The suitability map was created using 12 input maps as decision factor layers. All vector maps associated with the selected criteria and subcriteria were converted to a raster map with $30 \times 30$ $\mathrm{m}$ resolution. Each raster was then reclassiûed for all criteria and sub-criteria and values vi; ix; iy $(\mathrm{i}=$ $1,2 \ldots \mathrm{n}$ for each criterion at cell $(i x ; i y))$ were assigned to each new class.

The AHP Pair-wise comparison matrix was selected for the decision rules to analyze the data for landfill site selection using GIS. The 9-point scale used in typical analytic hierarchy studies ranges from 1 (indifference or equally preferred) to 9 (extreme preference or absolute importance). This pairwise comparison enables the decision maker to evaluate the contribution of each factor to the objective independently, thereby simplifying the decision making process factor as shown in Table 6.

A matrix was constructed where each criterion was compared with the other criteria relative to its importance, based on the pairwise comparison scale of 1 to 9 . Then, a weight estimate was calculated and used to derive a consistency ratio (CR) of the pairwise comparisons, If CR >

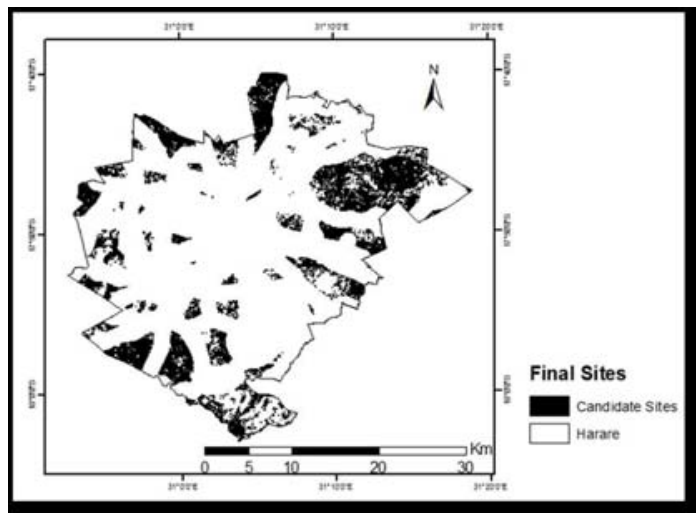

Fig. 14. Mask prepared to exclude the restricted areas
0.10 , then some pairwise values need to be reconsidered and the process is repeated until the desired value of $\mathrm{CR}<0.10$ is reached (Saaty, $\mathrm{T}$. $\mathrm{L}$, 1993).

The Weighted Linear Combination method is applied to compute the suitability index value of the potential areas based on the equation (equation 1 ):

$$
\mathrm{S}_{\mathrm{i}}=\sum^{\mathrm{n}}{ }_{\mathrm{j}=1} \mathrm{wj} \cdot \mathrm{xij}
$$

Where $S i$ is the suitability index for area $i$, $w j$ is the relative importance weight of criterion $j$, $x i j$ is the grading value of area $i$ under criterion $j$ and $n$ is the total number of criteria.

In this study, classification and rating of classes for every criterion was based on data obtained from secondary sources (Sener 2010; EPA 1993; EPA 2006; Kabite 2011; Khanlari 2012). The relative importance or preference of criteria was determined using the pair-wise comparison matrix in which Saaty's nine-point weighing scale was applied. In this step, all identified factors were compared against each other in a pair wise comparison matrix which is a measure of relative importance/preference among the factors as numerical values.

Weights are assigned to maps to express the relative importance. In order for the output map to be meaningful and consistent, map weights had to add up to $100 \%$ and the attribute scores had to be chosen using a scheme that was the same for each map. Every criterion was evaluated by a point allocation approach. All scored maps were then assigned to a common scale (e.g. ranging between 1 and 10), where 0 indicates that the point is not suitable and 10 represents the best situation for that criterion.

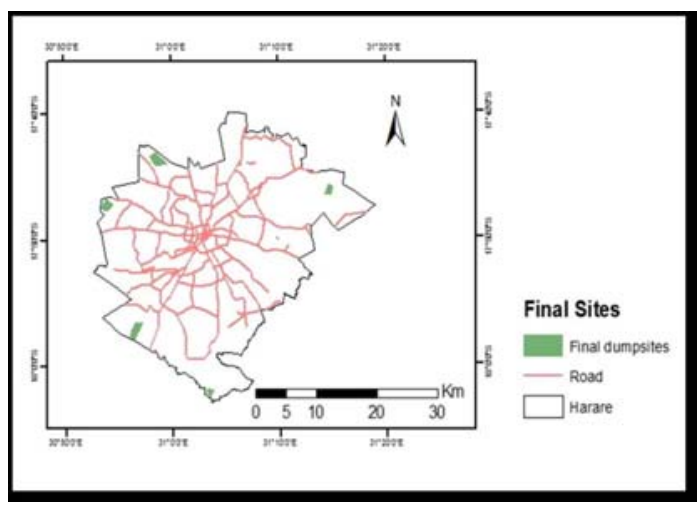

Fig. 15. Recommended landfill sites 


\section{Identification of Suitable Area}

The final step of the AHP process was to obtain a combined reclassiûed AHP + GIS suitability map with the constraint maps in order to obtain a final landfill. The relative importance of criterion to each other was calculated using AHP. Table 7 shows relative importance (weight) of the criteria used to evaluate suitability of each site. The results revealed that among the criteria analyzed, sensitive ecosystems (protected areas); surface water and elevation were the most important. Proximity to roads and railways was found to be the least important criteria.

\section{Constraint Maps}

Constraint (binary) maps are used to distinguish between areas that are suitable for landfill siting and those lands that are not suitable. The constraint maps are produced by overlaying and merging each individual theme (parameter) with the study area. Two classes defined for each theme and a value of 1 was assigned to suitable areas and 0 unsuitable areas. The constraint maps that were created are road network, railway network, river network, airport map, protected areas and land use map.

\section{Land-Cover/Land Use Map}

Land cover is an important criterion in landfill siting because landfill operations, such as drilling, leads to destruction of land cover. Landfills cannot be located in wetlands and forest areas; therefore, the grading value for these areas was 0 . Areas with irrigated farming lands that are important in agricultural activities received a score of 3. Dry farming lands and bare area were considered optimal for landfill siting (Figure 3).

According to Allen (2002), the distance from urban centers should be at least $5 \mathrm{~km}$ and from isolated houses $500 \mathrm{~m}$ to locate a landfill site. Taking into account all these parameters, Land cover suitability map was obtained (Figure 4).

\section{Roads Network, Railways and Airport}

Landfill location must be close to roads network in order to facilitate transportation and consequently to reduce relative costs. A buffer of $1,000 \mathrm{~m}$ was used in this study for the roads and railways. A direct relationship between distance from roads and land suitability is started at a 1,000 $m$ distance from the road's center-line. Railway lines and Harare airport with their buffer zones were also taken into account. As stated by Allen (2002), distance of $>3 \mathrm{~km}$ from flight path should be considered as a buffer zone (Figure 5 - a,b,c).

\section{Proximity to Rivers}

Areas which are located close to surface water sources are not suitable for landfill placement Based on the landfill siting regulations of the Environment Management Agency, disposal of solid waste near to any surface water body, such as lakes and rivers, is forbidden; the minimum distance of landfill sites from surface water should be more than $1000 \mathrm{~m}$. Figure 6 shows rivers network with buffers.

\section{Environmentally Sensitive Areas (Protected Areas)}

This criterion concerns with natural features that may be exposed by the threats imposed because of landfill adjacency. A landfill must not be located in close proximity to sensitive areas such as fish sanctuaries, mangrove areas, wildlife conservancy areas and areas gazetted for special protection should be excluded. Therefore a $500 \mathrm{~m}$ buffer is necessary to surround an environmentally sensitive area. A lesser buffer within the landfill may be provided where it is considered compatible with the surrounding area and land uses so that there will be an effective buffer of 500 meters between the landfill and any potentially sensitive or incompatible land use (EPA, 2007).

Three protected areas were identified in the study area; Mukuvisi Woodlands; Cleveland Range and Epworth balancing rocks and a $500 \mathrm{~m}$ buffer zone was created around each area (Fig. 7). Final Constraint Map

All constraint maps were overlaid and merged with the study to create one map (Figure 8). This vector map was converted to a raster map for further analysis.

\section{Factor Maps}

Factor maps illustrate suitability of a specified feature that ranges from the least suitable locations to the most suitable locations using a range of classes. Three factor maps created are: soil type map, slope and elevation.

Areas with high clay content are more suitable for landfill siting. Percentage of clay content in soils was used to determine suitability. The clay content in the soils of the study area ranged from $0-81 \%$. Sites in clay-rich environments are preferable, due to the low permeability, good workability and superior leachate retaining 
characteristics of these soils. Sufficient soil should also be available at the site to provide adequate covering for wastes. Figure 9 shows suitability according to clay content.

Slope map was generated from Digital Elevation Model (DEM) which is shown in Figure 10. The distribution of slope values in the study area ranges between 0 and $43.31 \%$.

The elevation map of the study area was divided into two regions. The areas with elevations between $750 \mathrm{~m}$ and 1,400 $\mathrm{m}$ were defined as suitable areas for a landfill site and the remaining areas as unsuitable (Fig. 11).

Areas with a slope value greater than $20 \%$ are not suitable to place landfills (Leao et al., 2003). Therefore in the study area these were classified as unsuitable. Areas with an elevation value $>1,400$ $\mathrm{m}$ were also classified as unsuitable. The suitable slope map and elevation map were overlaid and the results are shown in Fig. 12.

\section{Final Factor Map}

The final factor map was created using an arithmetic overlay when all factor maps were completed (Figure 13).

\section{Suitability Map}

The Final Constraint map (Figure 8) and the Final Factor map (Figure 13) were overlaid and merged to produce final suitability map with candidate sites (Figure 14). The selection of candidate sites was done using the masking operation. To prepare a mask of unsuitable areas, all data layers are multiplied by each other so that if any pixel has a value of 0 coming from any layer, then the value of that pixel will become 0 which means that the pixel is completely unsuitable to locate a landfill site. The white areas in the mask are excluded areas shown in Figure 14. The total area of all restricted areas is 710.46 square kilometers which is $73.96 \%$ of the total area of Harare. Therefore, an area of $250.14 \mathrm{~km}^{2}(26.04 \%)$ is suitable for landfill construction.

\section{Landfill Site Evaluation}

Selection of the final landfill site was determined by Accessibility and Site Capacity. It means that areas which are closer to existing roads are more suitable because there will be no need to construct new roads which lowers construction costs. On the other hand a site should provide a minimum of 15 years of use in order to minimize costs for site establishment and closure, smooth running of operations, and provision of adequate time for acquiring the next site. The larger the area of the site the more suitable it is. A large area is needed to enable establishment of a tipping area, separation area, gas and leachate treatment area as well as a recycling area. Figure 15 below shows areas which are most suitable and recommended for landfill construction based on site capacity and accessibility.

A total of 6 sites were identified in the study area as the most suitable areas. The total area of these sites is $12.63 \mathrm{~km}^{2}$ which is $1.31 \%$ of the total area of Harare. Further screening of the sites is required to choose the preferred site for purposes of final design, full environmental impact assessment and public participation activities adequate to meet EMA requirements.

To locate the most suitable sites, ground field surveys are required, these include:

\section{Groundwater level assessment}

A deeper water table region is suitable so that underground water is not contaminated by the leachates from the waste. North Dakota Department of Health (2009) explained that the bottom of disposal trench should be at least 2 meters above the water table (equivalent to about 1.20 meters).

\section{Geological survey}

In the selection of a site for MSW landfill, the underlying foundation soil and bedrock characteristics: geologic structure and existing fractures should be analyzed. These aspects affect the movement of leachate.

An environmental impact assessment has to be conducted as a requirement of the regulations of EMA. The environmental impact assessment and public participation activities will provide input to the final design (as part of an interactive process of design and environmental/public assessment which is required by EMA in order to obtain an optimally environmentally acceptable and cost effective design). The final design will incorporate mitigation measures to address potential adverse impacts on the environment and significant public concerns.

\section{CONCLUSION}

Landfill site selection and evaluation is a complicated process because it must combine social, environmental and technical factors. The 
data often involve processing of a significant amount of spatial data which can be used in GIS as it is an important tool for land use suitability analysis. Different tools and techniques have been developed for solid waste disposal site selection. Using Geospatial approach definitely improves the decision making capability and understanding of solid waste management by planners in urban areas. The multi criteria decision analysis is also a useful tool in making landfill siting decisions through ranking and weightings of the potential sites.

Six candidate sites were suggested based on the available data and methods applied in this research. Generally, the suggested sites comply with the minimum requirements of the landfill sites. The planners and the decision makers can get useful information about the possible locations of landfill sites using the results of this study. Especially considering that the site ranking process allows readjustment of the criteria weights in case a sensitivity analysis. The criteria used in this study are not fixed since they can vary from place to place and these criteria can be changed accordingly

By developing sustainable growth policies, local governments in partnership with the community, can improve the quality of life of citizens and contribute to protecting the environment. The waste management authorities in Harare need to embrace the 3R, Reduce, Recover and Recycle concept of solid waste management as part of sustainable development aimed at increasing the life span of the new landfill, because only $10 \%$ of the total waste generated in Harare is recovered and recycled.

\section{REFERENCES}

1. Practical Action., Emerging Issues in Urban Waste Management. Available online, http:// practicalaction.org/docs/region_southern_africa, 2006.

2. Kjellen, M., Health and environment, Stockholm, Swedish International Development Cooperation Agency, 2001.

3. Housing and Community Services, City of Harare, personal communication, 2011.

4. Mupedziswa and oth. Developmental Social work Education in Southern and East Africa, 2009. http://resourcecentre.savethechildren.se/ sites/default/files/documents/5089.pdf

5. GoZ. Environmental Management Act Chapter 2011; 20: 27. Government of Zimbabwe Publications, http://www.cbd.int/doc/measures/ abs/msr-abs-zw-en.pdf

6. Waste Management Research Trend. Editor: Toma V. Golush / Solid Waste Settlement in Landfills. Waris and Fikry H. Ghobrial, Sherien A et al., Nova Science Publishers, Inc., New York 2008, ISBN 978-1-60456-234-7

7. Allen A., Attenuation: A Cost Effective Landfill Strategy for Developing Countries. In Engineering Geology for Developing Countries. Proc. 9-th Congress. Durban, South Africa. 2002; 156-157

8. Masocha, M., Solid Waste Disposal in Victoria Falls Town: Spatial Dynamics, Environmental Impacts, Health Threats and Socio-economic Benefits, Unpublished Thesis, Geography and Environmental Science. Harare, University of Zimbabwe, 2003.

9. M.S.Eukay, Kharlamova M., An assessment of the relationship between the spatial distribution of undesignated dumpsites and disease occurrence in Budiriro, Harare, Zimbabwe // Science, Technology and Higher Education. Materials of the V International Conference. June $20^{\text {th }}, 2014$ /- Westwood- Canada -2014. P.236-242 ISBN 978-1-77192-087-22014

10. UNEP., Managing the environment in developing countries, Available online, www.unepwcmc.org, 2011.

11. R Tsiko; S Togarepi, A situational analysis of waste management in Harare Zimbabwe, Journal of American Science 2012; 4: 692-707

12. WHO, Zimbabwe cholera and health situation, Available online, www.who.int/disasters, 2013.

13. Feresu, S.B. (ed.) Zimbabwe Environment Outlook: Our Environment, Everybody's Responsibility. The Ministry of Environment and Natural Resources Management, Government of the Republic of Zimbabwe, Harare, Zimbabwe, 2013.

14. Saaty TL, The analytic hierarchy process: a 1993 overview. Central European Journal of Operation Research and Economics 1993; 2: 119-137.

15. Sener S, Sener E, Nas B and Karagüzel R., Combining AHP with GIS for landfill site selection: A case study in the Lake Beysehir catchment area (Konya, Turkey). Waste Management 2010; 30: 2037-2046. 